\title{
Food deprivation does not affect growth performance of juvenile tambacu
}

\author{
Arlan de Lima PAZ ${ }^{1,3^{*}}$, Yugo Moraes PASTRANA ${ }^{2,3}$, Lian Valente BRANDÃO ${ }^{4}$ \\ Instituto Nacional de Pesquisas da Amazônia - INPA, Laboratório de Ecofisiologia e Evolução Molecular, Ave. André Araújo 2936, CEP 69067-375, Manaus, AM, Brasil \\ 2 Universidade Nilton Lins, Laboratório de Reprodução Animal, Ave. Professor Nilton Lins 3259, CEP 69058-030, Manaus, AM, Brasil \\ 3 Universidade Nilton Lins, Programa de Pós-graduação em Aquicultura, Ave. Professor Nilton Lins 3259, CEP 69058-030, Manaus, AM, Brasil \\ 4 Instituto Federal de Educação, Ciência e Tecnologia do Pará (IFPA), BR 316, Km 61, CEP 68740-970, Castanhal, PA, Brasil \\ * Corresponding author: arlanpaz.inpa@gmail.com
}

\section{ABSTRACT}

The objective of this study was to evaluate the efficiency of food deprivation on the growth performance of the commercially important hybrid fish tambacu (Piaractus mesopotamicus male $\times$ Colossoma macropomum female). For this, 171 juveniles of average length $8 \mathrm{~cm}$ and $11.4 \mathrm{~g}$ body mass were distributed in nine tanks, and allocated to three treatments: the fish were fed every day (control), fed for six days followed by one day of food deprivation (6F/1D) and fed for five days followed by two days of food deprivation (5F/2D). After 77 days, all animals achieved similar growth rates. Only animals submitted to two days of food deprivation presented hyperphagia. There was a reduction in total feed consumption of $3.8 \%$ and $10.8 \%$ for the $6 \mathrm{~F} / 1 \mathrm{D}$ and $5 \mathrm{~F} / 2 \mathrm{D}$ treatments, respectively. Our results suggest that juvenile tambacu exhibit total compensatory growth when submitted to food deprivation, and that a two-day deprivation could significantly reduce production costs for tambacu farmers.

KEYWORDS: fish farming, feeding strategy, compensatory growth

\section{Privação alimentar não afeta o crescimento de juvenis de tambacu}

\section{RESUMO}

O objetivo do estudo foi avaliar a eficiência da privação alimentar sobre o desempenho zootécnico de tambacu (Piaractus mesopotamicus x Colossoma macropomum). Para isso, 171 animais (massa: 11,4 \pm 1.5 g; comprimento total: $8.0 \pm 0.4 \mathrm{~cm}$ ) foram alocados em nove tanques (19 peixes/tanque; $n=3$ ). Os peixes foram alimentados todos os dias (controle), alimentados durante seis dias seguidos de um dia de privação alimentar (6F/1D) e durante cinco dias seguidos de dois dias de privação alimentar (5F/2D). Após 77 dias, todos os animais alcançaram índices de crescimento similares. Somente os animais submetidos a dois dias de privação apresentaram hiperfagia. Houve redução do consumo total de ração em 3,8 e 10,8\% para os tratamentos $6 \mathrm{~F} / 1 \mathrm{D}$ e $5 \mathrm{~F} / 2 \mathrm{D}$, respectivamente. Os nossos resultados demonstram que os juvenis de tambacu exibiram crescimento compensatório total quando submetidos a privação alimentar, e a estratégia de 2 dias de privação alimentar pode reduzir significativamente os custos de produção de tambacu.

PALAVRAS-CHAVE: piscicultura, estratégia alimentar, crescimento compensatório

There is a demand to reduce fish feed costs, which account for about $70 \%$ of the variable production costs in aquaculture (Lovell 1998; HLPE 2017). Food deprivation followed by refeeding is a management strategy adopted to induce compensatory growth, and is described as an accelerated growth phase when initial/abundant food conditions are reestablished after a food deprivation period (Ali et al. 2003; Hornick et al. 2000). The efficient implementation of this type of food management strategy can help reduce production costs and increase profits for fish farmers without compromising the zootechnical and physiological performance of the fish (Santos et al. 2010; Ali et al. 2016).
The tambacu is a hybrid between two closely related Serrasalmidae species: a male pacu (Piaractus mesopotamicus) and a female tambaqui (Colossoma macropomum). This hybrid represents $10.1 \%$ of the total production value of Brazilian commercial fish farming (IBGE 2016). It is therefore desirable to investigate food deprivation as a management strategy for tambacu. The aim of this study was to evaluate the efficiency of short-term food deprivation for the zootechnical performance of tambacus.

The experiment was carried out at the school farm Castanhal (FEC) $\left(01^{\circ} 18^{\prime} 02^{\prime \prime} S\right.$; $\left.48^{\circ} 05^{\prime} 05^{\prime \prime} \mathrm{W}\right)$ of the Federal Rural University of Amazonia (UFRA), at Castanhal, Pará 
state, Brazil, from September 10 to November 26, 2012. We used nine concrete tanks, each containing $2.45 \mathrm{~m}^{3}$ of water. The system was supplied with water from an upstream dam, with the flow of each tank adjusted to $0.2 \mathrm{~L}_{\text {minute }}{ }^{-1}$, and a natural photoperiod. Water quality was monitored daily during the experimental period. Dissolved oxygen concentration $\left(4.16 \pm 0.15 \mathrm{mg} \mathrm{L}^{-1}\right)$, temperature $(28.8 \pm$ $\left.0.9^{\circ} \mathrm{C}\right)$ (Digital Oximeter OD-2000), $\mathrm{pH}(6.8 \pm 0.1)$, and total ammonia concentration $\left(0.001 \pm 0.001 \mathrm{mg} \mathrm{L}^{-1}\right)$ (SERA AQUA-TEST BOX ${ }^{\oplus}$ kit) were measured.

Tambacu juveniles (mass: $11.4 \pm 1.5$ g; length: $8.0 \pm 0.4$ $\mathrm{cm}$ ) were purchased from a private producer, acclimated for 30 days under the above mentioned conditions, and distributed in the nine tanks (19 fish tank ${ }^{-1}$ ), totaling 171 individuals, in a completely randomized design with three treatments (each with three tank replicates): fish fed daily (control); fish fed for six days, followed by one day of food deprivation (6F/1D), and fish fed for five days, followed by two days of food deprivation (5F/2D).

The fish were fed twice daily (8:00 am and 4:00 pm), for 77 days, until apparent satiation with commercial extruded feed containing $32 \%$ crude protein $(\mathrm{CP})$ and granulometry of $4-6 \mathrm{~mm}$ (Guabi - Pirá, São Paulo, Brazil). The total feed consumption (TFC) was determined as follows:

$$
\begin{aligned}
\text { TFC }(\mathrm{g})= & \Sigma \text { [amount of feed consumed }(\mathrm{g}) \text { in the } \\
& \text { period }]- \text { dry feed leftovers }
\end{aligned}
$$

At the end of the experiment, all animals were anesthetized with Eugenol ${ }^{\circ}$ diluted in $70 \%$ alcohol in the ratio of 1 part anesthetic: 4 parts alcohol: 100 parts water (adapted from Roubach et al. 2005). The animals were then weighed on a digital scale (WESTERN ${ }^{\odot}$ KC-01) and the standard length was measured with an ichthyometer.

Growth performance was evaluated by weight gain (WG), final length (FL) and specific growth rate (SGR). The feed utilization was assessed by total feed consumption (TFC), feed conversion rate (FCR) and condition factor $(\mathrm{K})$. These variables were calculated using the following mathematical expressions:

$$
\text { WG = final mass (FM) - initial mass (IM); }
$$

SGR $(\%$ day $):=[(\ln$ final weight $-\ln$ initial weight $)] /$ days of cultivation $\mathrm{x} 100$; TFC = quantity of feed consumed in the period;

FCR = amount of feed ingested (g)/weight gain in the period $(\mathrm{g})$;

$$
\mathrm{K}=\left[\text { mass }(\mathrm{g}) / \text { standard length }(\mathrm{cm})^{3}\right] \times 100 .
$$

Data were presented as the mean \pm standard deviation (SD) and tested for normality (Shapiro-Wilk test) and homoscedasticity (Cochran's test). We performed a one-way ANOVA, and, when necessary, we compared means using the Tukey post-hoc test $(\mathrm{p}<0.05)$.

There were no significant differences $(\mathrm{p}<0.05)$ among the three treatments for FM (g), FL (cm), WG (g) and SGR (Table 1 ), and no mortality was registeerd. There was a significant reduction in food intake for treatment $5 \mathrm{~F} / 2 \mathrm{D}$ when compared to that of the control (Table 2). Fishes from the 5F/2D treatment consumed significantly more feed on Mondays than the control group. On average, the $5 \mathrm{~F} / 2 \mathrm{D}$ group consumed $19.1 \mathrm{~g}$ of feed, compared to $14.4 \mathrm{~g}$ and $16.9 \mathrm{~g}$ for the control and the $6 \mathrm{~F} / 1 \mathrm{D}$ treatments, respectively. These results suggest that juveniles in treatment $5 \mathrm{~F} / 2 \mathrm{D}$ became hyperphagic (increased feed intake after refeeding) when food abundance was re-established (Figure 1). The feed conversion rate of the fish in the $5 \mathrm{~F} / 2 \mathrm{D}$ treatment was lower than that of the control group ( $\mathrm{p}=0.043)$ (Table 1).

The present study demonstrated the ability of juvenile tambacu to compensate growth after periods of food deprivation of one $(6 \mathrm{~F} / 1 \mathrm{D})$ and two $(5 \mathrm{~F} / 2 \mathrm{D})$ days per week. The fish submitted to the 5F/2D strategy consumed a significantly smaller amount of feed than did the animals kept under daily diet (control) and reached a similar mass gain.

During fasting (catabolic phase), the levels of ghrelin and growth hormone $(\mathrm{GH})$ are elevated, which in turn increases appetite and lipolysis, whereas insulin-like growth factors (IGFs) are eliminated (Won and Borski 2013). During

Table 1. Effect of different dietary deprivation strategies on final mass (FM), final length (FL), condition factor (K), mass gain (MG), feed conversion ratio (FCR) and specific growth rate (SGR) of tambacu (Piaractus mesopotamicus male $\times$ Colossoma macropomum female) juveniles. Values are the mean \pm SD ( $n=3$ ). Control: fish fed daily; 6F/1D: fish fed six days a week, followed by one day of food deprivation; 5F/2D: fish fed five days a week, followed by two days of food deprivation. Different lowercase letters in the same column indicate significant differences by ANOVA and Tukey test $(p<0.05)$.

\begin{tabular}{lcccc}
\hline \multirow{2}{*}{ Variables } & & Treatments & P \\
\cline { 2 - 3 } & Control & 6 F/1D & 5 V $/ 2 D$ & 0.321 \\
\hline FM (g) & $69.63 \pm 0.32$ & $68.39 \pm 3.72$ & $66.12 \pm 2.32$ & 0.222 \\
FL (cm) & $15.51 \pm 1.12$ & $15.33 \pm 1.31$ & $14.88 \pm 1.07$ & 0.168 \\
K & $1.86 \pm 0.08$ & $1.91 \pm 0.07$ & $1.99 \pm 0.05$ & 0.254 \\
MG (g) & $58.29 \pm 0.34$ & $57.08 \pm 3.92$ & $54.64 \pm 2.30$ & 0.043 \\
FCR & $0.93 \pm 0.02 \mathrm{a}$ & $0.91 \pm 0.01 \mathrm{ab}$ & $0.88 \pm 0.07 \mathrm{~b}$ & 0.217 \\
\hline SGR (\% per day) & $2.35 \pm 0.01$ & $2.33 \pm 0.07$ & $2.29 \pm 0.05$ & \\
\hline
\end{tabular}


Table 2. Total feed consumption (TFC) and reduction in the amount of feed supplied to juveniles of tambacu (Piaractus mesopotamicus male $\times$ Colossoma macropomum female) submitted to different strategies of food deprivation. Values are the mean $\pm S D(n=3)$. Control: fish fed daily; $6 F / 1 D$ : fish fed six times a week, followed by one day of food deprivation; 5F/2D: fish fed five times a week, followed by two days of food deprivation. Different lowercase letters in the same column indicate significant differences by the Tukey test $(p<0.05)$.

\begin{tabular}{lcc}
\hline Treatments & $\begin{array}{c}\text { TFC } \\
(\mathrm{g})\end{array}$ & $\begin{array}{c}\text { Feed reduction } \\
(\%)\end{array}$ \\
\hline Control & $1025.8 \pm 21.3^{\mathrm{a}}$ & 0 \\
$6 \mathrm{~F} / 1 \mathrm{D}$ & $986.6 \pm 58^{\mathrm{ab}}$ & 3.8 \\
$5 \mathrm{~F} / 2 \mathrm{D}$ & $915 \pm 10.8^{\mathrm{b}}$ & 10.8 \\
\hline
\end{tabular}

refeeding (anabolic phase), hyperphagia provides increased energy flow and metabolic substrates that are directed to somatic growth by restarted IGF signaling. Feedback redirects the growth path to its optimal state and the compensatory response decreases as energy reserves are reactivated and homeostasis is restored (Won and Borski 2013).

Food deprivation has been widely used in fish management in long cycles of deprivation without affecting productive performance (Souza et al. 2002; Ituassú et al. 2004; AbdelHakim et al. 2009; Santos 2011; Azodi et al. 2015). The improvement in feed efficiency during the feedback, is a good indicator of compensatory growth (Ali et al. 2003), as also noted in the present study, in addition to other studies using P. mesopotamicus, with FCR $=1.0$ (Souza et al. 2003) and hybrid tilapias (Oreochromis niloticus x Oreochromis aureus), with FCR $=0.8$ (Abdel-Hakim et al. 2009).

Increasing food efficiency, reducing metabolic costs and decreasing mobility are some of the mechanisms used by fish to reduce energy expenditure. Interestingly, these strategies are sometimes maintained during and after the refeeding period, which can contribute to the increase in mass gain (Hornick et al. 2000). Accordingly, no loss of mass gain was observed for tinfoil barbs (Barbonymus schwanenfeldii) after an 11.3\% reduction in feed consumption (Eslamloo et al. 2012). Similar results were obtained by Palma et al. (2010) who exposed Nile tilapia (GIFT strain) to 5 days of feeding and 2 days of feed deprivation $(36.57 \%$ reduction of feed consumption with no significant loss of mass gain).

In conclusion, our results suggest that juvenile tambacu exhibit total compensatory growth when submitted to food deprivation followed by refeeding, and that a two-day feed deprivation per week can reduce feed intake by up to $10.8 \%$. Therefore, based on our results, we suggest that using food deprivation on two days (5F/2D strategy), for example, on Saturdays and Sundays, could reduce significantly the production costs of tambacu rearing.

\section{ACKNOWLEDGMENTS}

We thank the experimental station of Universidade Federal Rural da Amazônia - UFRA and Instituto Federal do Pará (IFPA) for structural and logistic support. We thank

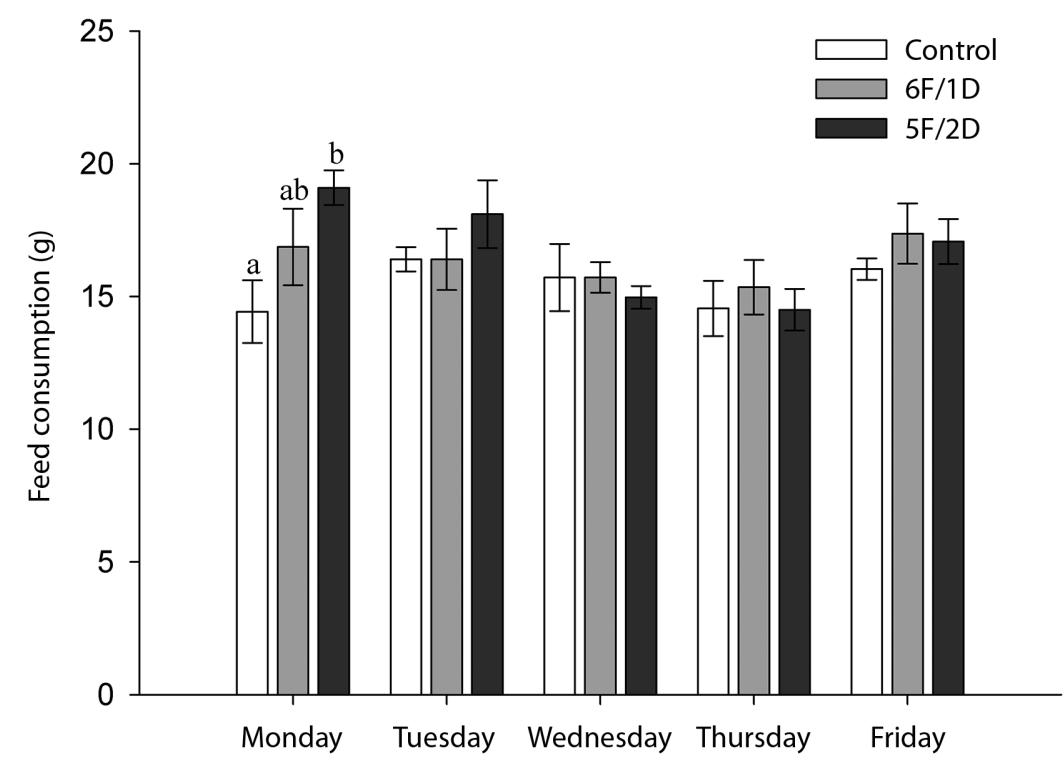

Figure 1. Total feed consumption aay ' Ig) or tampacu juvenıes (riaractus mesopotamıcus maıe x coıossoma macropomum temaıe) aurıng 77 days. Columns represent the mean and the bars on top represent the standard deviation ( $n=3)$. Control: fish fed daily; 6F/1D: fish fed six days a week, followed by one day of food deprivation; 5F/2D: fish fed five days a week, followed by two days of food deprivation. Different lowercase letters indicate significant differences between the treatments by the Tukey test $(p<0.05)$. 
researchers Joaquim Câncio and Thiago Santos for their help in the execution of the experiment, François-Étienne and Leandro Godoy for their help with the translation.

\section{REFERENCES}

Abdel-Hakim, N.F.; Abo State, H.A.; Al-Azab, A.A.; El-Kholy, K.H.F. 2009. Effect of feeding regimens on growth performance of juvenile hybrid tilapia (Oreochromis niloticus $\times$ Oreochromis aureus). World Journal of Agricultural Sciences, 5: 49-54.

Ali, M.; Nicieza, A.; Wootton, R.J. 2003. Compensatory growth in fishes: a response to growth depression. Fish and Fisheries, 4: $147-190$.

Ali, T.E.S; Martínes-Llorens, S.; Moñino, A.V.; Cerdá, M.J.; Tomás-Vidal, A. 2016. Effects of weekly feeding frequency and previous ration restriction on the compensatory growth and body composition of Nile tilapia fingerlings. Egyptian Journal of Aquatic Research, 42: 357-363.

Azodi, M.; Ebrahimi, E.; Farhadian, O.; Mahboobi-Soofiani, N.; Morshedi, V. 2015. Compensatory growth response of rainbow trout Oncorhynchus mykiss Walbaum following short starvation periods. Chinese Journal of Oceanology and Limnology, 4: 928-933.

Eslamloo, K.; Morshedi, V.; Azodi, M.; Ashouri, G.; Ali, M.; Iqbal, F. 2012. Effects of Starvation and Re-Feeding on Growth Performance, Feed Utilization and Body Composition of Tinfoil Barb (Barbonymus schwanenfeldii). World Journal of Fish and Marine Sciences, 4: 489-495.

HLPE. 2017. Nutrition and food systems. A report by the High Level Panel of Experts on Food Security and Nutrition of the Committee on World Food Security. 44th ed. Committee on World Food Security (CFS), Rome, 150p

Hornick, J.L.; Van Eenaeme, O.; Gérard, I.; Dufrasne, L.; Istasse, L. 2000. Mechanism of reduced and compensatory growth. Domestic Animal Endocrinology, 19: 121-132.

IBGE. 2016. Produção da Pecuária Municipal. v.44. Instituto Brasileiro de Geografia e Estatística - IBGE. Rio de Janeiro, RJ - Brasil, 51p.
Ituassú, D.R.; Santos, G.R.S.; Roubach, R.; Pereira-Filho, M. 2004. Desenvolvimento de tambaqui submetido a períodos de privação alimentar. Pesquisa Agropecuária Brasileira, 39: 1199-1203.

Lovell, R.P. 1998. Nutrition and feeding of fish. 2nd ed. Kluwer Academic Publishers, Boston, New York, 260p.

Palma, E.H.; Takahashi, L.S.; Dias, L.T.S.; Gimbo, R.Y.; Kojima, J.T.; Nicodemo, D. 2010. Estratégia alimentar com ciclos de restrição e realimentação no desempenho produtivo de juvenis de tilápia do Nilo da linhagem GIFT. Ciência Rural, 40: 421-426.

Roubach, R.; Gomes, L.C.; Fonseca, F.A.L.; Val, A.L. 2005. Eugenol as an efficacious anaesthetic for tambaqui, Colossoma macropomum (CUVIER). Aquaculture Research, 36: 1056-1061.

Santos, L.; Filho, M.P.; Sobreira, C.; Ituassú, D.; Fonseca, F.A.L. 2010. Exigência proteica de juvenis de tambaqui (Colossoma macropomum) após privação alimentar. Acta Amazonica, 403: 597-604.

Santos, M.S. 2011. Crescimento compensatório de juvenis de matrinxã Brycon amazonicus (SPIX \& AGASSIZ, 1829). Master's dissertation, Fundação Universidade Federal do Rio Grande, Rio Grande, $42 \mathrm{p}$

Souza, V.L.; Urbinati, E.C.; Gonçalves, D.C.; Silva, P.C. 2002. Composição corporal e índices biométricos do pacu, Piaractus mesopotamicus Holmberg, 1887 (Osteichthyes, Characidae) submetido a ciclos alternados de restrição alimentar e realimentação. Acta Scientiarum, 24: 533-540.

Souza, V.L.; Urbinati, E.C.; Martins, M.I.E.G.; Silva, P.C. 2003. Avaliação do crescimento e do custo da alimentação do pacu (Piaractus mesopotamicus Holmberg, 1887) submetidos a ciclos alternados de restrição e realimentação. Revista Brasileira de Zootecnia, 32: 19-28.

Won, E.T.; Borski, R.J. 2013. Endocrine Regulation of Compensatory Growth in Fish. Frontiers in Endocrinology, 4: 74.
RECEIVED: $15 / 02 / 2018$
ACCEPTED: 05/05/2018
ASSOCIATE EDITOR: Rodrigo do Valle 